\title{
Effect of additives on the physical and chemical characteristics of sugar cane silage
}

\author{
Efeito de aditivos sobre as características físicas e químicas de \\ silagens de cana de açúcar
}

\author{
Patricia do Rosario Rodrigues ${ }^{1 *}$; Antonio Delunardo Pandolfi Filho ${ }^{2}$; \\ Bráulio Pêgo de Faria ${ }^{3}$; Guilherme Santos Freitas²; Rodrigo Santos Freitas 4 ; \\ Bruno Borges Deminicis ${ }^{5}$
}

\begin{abstract}
The objective of this study was to verify the efficiency of different additives on chemical composition, $\mathrm{pH}$, ethanol production, content of volatile fatty acids (VFAs), nutritional losses during fermentation, and changes in fibrous fractions, in the levels of non-fibrous and total carbohydrates during the sugar cane silage fermentation process with different additives. The treatments consisted of control (no additive); corn meal, at $10 \%$ of natural matter; molasses, at $10 \%$ of natural matter; urea, at $2 \%$ of natural matter;

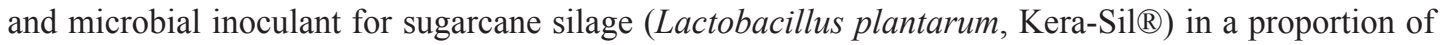
$2 \mathrm{~g} \mathrm{~L}^{-1}$ of water using a 2 liter solution per ton of ensilage. The experimental design was a completely randomized design with five treatments and five replications. The urea treatment provided the best preparation of silage, taking into account the $\mathrm{pH}$ and bromatological composition when compared to silages made with the other tested additives, and the control. The sugarcane silage showed a loss of $5.86 \%$ on average of dry matter, not differing from others additives used. There was an increase in crude protein content when urea was used. There was no difference between the treatment for fiber losses in neutral detergent and total digestible nutrients.
\end{abstract}

Key words: Aerobic stability, chemical composition, forage conservation, silage

\section{Resumo}

Objetivou-se com o presente estudo verificar a ação de diferentes aditivos sobre a composição química, pH, produção de etanol, teor de Ácidos Graxos Volateis - AGV's, perdas nutricionais durante a fermentação, as alterações nas frações fibrosas, nos teores de carboidratos não fibrosos e totais durante o processo fermentativo das silagens de cana de açúcar com diferentes aditivos. Os tratamentos consistiram

\footnotetext{
${ }^{1}$ Zootecnista, Discente do Curso de Doutorado em Produção e Nutrição de Ruminantes do Programa de Pós Graduação em Zootecnia, Universidade Federal de Lavras, UFLA, Lavras, MG, Brasil. Bolsista CNPQ. E-mail: patriciarodrigues_zootec@ hotmail.com

2 Zootecnistas, Mestres em Ciências Veterinárias pelo Programa de Pós Graduação em Ciências Veterinária, Universidade Federal do Espírito Santo, UFES, Alegre, ES, Brasil. Bolsista CAPES. E-mail: pandolfizoo@hotmail.com; guilhermesantosfreitas@ hotmail.com

${ }^{3}$ Médico Veterinário, Discente do Curso de Mestrado em Ciências Veterinárias no Programa de Pós Graduação em Ciências Veterinária, Universidade Federal do Espírito Santo, UFES, Alegre, ES, Brasil. E-mail: braulio_faria@hotmail.com

${ }^{4}$ Zootecnista, Pesquisador do Ministério da Agricultura, Pecuária e Abastecimento, Florianópolis, SC, Brasil. E-mail: rodrigosantosfreitas@hotmail.com

5 Prof. Adjunto, Universidade Federal do Sul da Bahia, UFBA, Teixeira de Freitas, BA, Brasil. E-mail: brunodeminicis@gmail. com

* Author for correspondence
} 
em controle (sem aditivo); fubá de milho, a 10\% da matéria natural; melaço, a 10\% da matéria natural; ureia, a $\%$ da matéria natural e inoculante microbiano para silagem de cana de açúcar (Lactobacillus plantarum - Kera-Sil $\left.{ }^{2}\right)$, na proporção de $2 \mathrm{~g} \mathrm{~L}^{-1}$ de água, utilizando 2 litros da solução por tonelada ensilada. $\mathrm{O}$ delineamento experimental utilizado foi o inteiramente casualizado com 5 tratamentos e 5 repetições. O tratamento com ureia proporcionou a confecção da melhor silagem, levando em consideração o pH e composição bromatológica quando comparadas às silagens confeccionadas com os outros aditivos testados e a silagem controle. A cana de açúcar ensilada apresentou perda de matéria seca de 5,86\% em média, não diferindo quanto aos aditivos utilizados. Houve acréscimo no teor de proteína bruta quando utilizado o aditivo ureia. Não houve diferença entre os tratamentos para perdas de fibra em detergente neutro e nutrientes digestíveis totais.

Palavras-chave: Composição química, conservação de forragem, ensilagem, estabilidade aeróbia

\section{Introduction}

Sugar cane is widely used in the feeding of ruminants due its high potential production of dry matter (DM) and energy per unit area, being used mainly in in natura and silage forms (PIRES et al., 2010). It has great forage potential for its cutting coincide with the period of low forage production (dry), being well used as a supplement in winter because of its low production cost and high efficiency, as it keeps its nutritional value (BALIEIRO NETO et al., 2007).

Currently, the conservation of cane sugar in the form of silage has aroused great interest of both producers and researchers, by virtue of its benefits on logistics and operational readiness. The silage is based on natural fermentation of forage, in which bacteria convert sugar that is soluble in organic acids: acetic, lactic, propionic and butyric acid (SCHMIDT et al., 2007). On the other hand, the sugar cane silage has also been used because it has the main prerequisites: dry matter content around $25-30 \%$ (ideal $35 \%$ ) and the low buffering capacity, which allows the fall of $\mathrm{pH}$ to levels close to 3.5 (ideal 3.8-4.2). (PÁDUA et al., 2014). This process has excelled in the feeding of ruminants, with the objective of minimizing the operation of machines in the field for sugar cane cutting and transport; also, it results in increasing productivity and life of the plantations due to greater efficiency in post-harvest care. The biggest obstacle for using silage consists of high ethanol production. Due to the high content of soluble carbohydrates, silage presents a rapid proliferation of yeasts, since these microorganisms are in anaerobiosis, ferment carbohydrates, and produce ethanol. The vast majority of what is employed in ruminant feed fodder during droughts has a high content of fiber and low content of crude protein (CP), which consequently will result in low digestibility of dry matter (DM). This situation can be mitigated through the use of additives in the silage process, i.e. use of physical, chemical, or biological treatments, which promote high nutritional value in forage making it more digestible to the animal, especially because of changes in the cell wall.

Urea and inoculants are additives already widely used in silage processes; in addition, a sustainable option might be the use of molasses by-products. Molasses can be employed in silage as a substrate rich in sugars and minerals (manganese, sodium, phosphorus, zinc, potassium), being an excellent substrate for the cultivation of acid lactic acid bacteria (DELGADO, 1975).

The aim of this study to verify the efficiency of different additives on the chemical composition, $\mathrm{pH}$, ethanol production, content of VFAs, losses, and changes in levels of fiber fractions in non-fibrous and total carbohydrates during the fermentation process of sugar cane silage with different additives.

\section{Material and Methods}

The experiment was conducted on private property-Olho d'água, geolocation coordinates 
$-20^{\circ} 45^{\prime} 35.82^{\prime \prime},-41^{\circ} 25^{\prime} 37.64 \prime$ in Alegre-ES, and qualitative characteristics analyses were performed at the food science laboratory in the Department of Animal Science Federal University of Espírito Santo (UFES).

The material was ensiled in laboratory bag silos with a capacity of approximately $10 \mathrm{~kg}$ per experimental unit, totaling 25 experimental units. The crushed material compression was performed with iron canes aiming to reach 1 ton $\mathrm{m}^{-3}$ density of forage. After compression of the forage, the silos were sealed with tape, weighed, and stored. The bag silos were kept in the laboratory of forage production and pastures, in the shade, and at an ambient temperature.

The design used in this study was a completely randomized design, with five treatments (control, ground corn, molasses, urea, and inoculant) and five repetitions. The treatments consisted of control (without additive); corn meal, 10\% natural matter; molasses, $10 \%$ natural matter; urea, 2\% natural matter; and microbial inoculant for silage sugar cane (Lactobacillus plantarum, Kera-Sil $®$ ), at a rate of $2 \mathrm{~g} \mathrm{~L}-1$ of water, using 2 liters of solution per clamped ton, i.e. $4 \mathrm{~g}$ of inoculant per ton, with the inoculant dissolved in clean water and chlorinefree. The additives were added in forage mass, homogenously.

At the moment silage was performed withdrew aliquots of 600 grams (previously processed on forage chopper, with adjustment of the blades to obtain particles of size $1.5 \mathrm{~cm}$ ) to determine the chemical composition of the natural material. By following were placed in plastic bags and stored in the refrigerator for five days.

Once the material was removed from the refrigerator and exposed on countertops at room temperature, the thawing was done in trays. After thawing, it was withdrawn at a sub-rate of approximately 300 grams for drying. Drying was done in greenhouses with forced ventilation at 55 ${ }^{\circ} \mathrm{C}$ for 72 hours.

After drying, the samples were ground with a knife mill with $1 \mathrm{~mm}$ sieve for the determination of the levels of dry matter (DM), crude protein (CP), neutral detergent fiber (NDF), ether extract (EE), ashes (ASH) and total digestible nutrients (TDN) (Table 1).

Table 1. Chemical composition, dry matter (DM), crude protein (CP), neutral detergent fiber (NDF), ether extract (EE), ash (ASH) and total digestible nutrients (TDN) of the masses to be ensiled with different additives.

\begin{tabular}{lcccccc}
\hline \multicolumn{1}{c}{ Treatments } & DM\% & CP\% & NDF\% & EE\% & ASH\% & TDN\% \\
\hline Control & 28,43 & 1,41 & 49,01 & 1,70 & 3,44 & 63,35 \\
Corn meal & 34,11 & 1,37 & 37,75 & 0,82 & 5,71 & 68,04 \\
Molasses & 29,10 & 1,07 & 46,84 & 0,37 & 2,29 & 64,25 \\
Urea & 33,68 & 1,78 & 49,11 & 1,03 & 2,09 & 63,30 \\
Inoculant & 28,29 & 1,85 & 47,93 & 0,45 & 2,02 & 63,80 \\
\hline${ }^{*} \mathrm{CV} \%$ & 2,20 & 12,89 & 6,70 & 61,24 & 12,15 & 5,05 \\
\hline
\end{tabular}

* Coefficient of variation.

The silages were sampled 30 days after ensiling. In the collection of the samples, the $15 \mathrm{~cm}$ of the upper and lower portion of the silos were discarded after this procedure, the silage was homogenized.
Following this procedure, samples were taken from each experimental unit, and a hydraulic press was used for extraction from the separated samples. The juice from the silages were used to determine 
the levels of volatile fatty acids (acetic acid, propionic, butyric and lactic) and the concentration of ethanol as methodology described by Palmquist and Conrad (1971).

The analyses were performed at the Animal Nutrition Laboratory of the Federal University of Viçosa, with a high performance liquid chromatography (HPLC), SHIMADZU brand, SPD-10A VP model coupled to the ultraviolet detector (UV) using a wavelength of $210 \mathrm{~nm}$.

A second sample of approximately 600 grams was weighed and packaged in paper bags, placed in an oven with forced ventilation at $55^{\circ} \mathrm{C}$ for 72 hours. Then, the samples were removed from the oven, kept at room temperature for one hour and weighed to determine the dry matter. Subsequently, the samples were pounded in a Willey mill with $1 \mathrm{~mm}$ mesh sieve, and packed in glass with a lid for further analyses of $\mathrm{CP}$, ether extract (EE), ashes (ASH), neutral detergent fiber (NDF), hemicellulose (HEM), acid detergent fiber (ADF), lignin (LIG), and cellulose (CEL), according to the technique described by Silva and Queiroz (2009).

A third aliquot (50 grams) was withdrawn to perform the determination of $\mathrm{pH}$ in water for each silage. Non-fibrous carbohydrate levels (CNF) and total carbs (CHOT) were estimated using the following equations: $\mathrm{CNF}=100-(\mathrm{CP}+\mathrm{NDF}+\mathrm{ASH}+\mathrm{EE})$ e $\mathrm{CHOT}=$ 100-(CP+ASH+EE). The levels of total digestible nutrients (TDN) were obtained using the equation: $\mathrm{TDN}=83.79-0.4171 \mathrm{NDF}$ proposed by Cappelle et al. (2001).
The nutrient losses of nutrients were expressed by the difference in gradients between original material and the ensiled material, associated with the weight of "bags" during the ensiling process and after opening the silos, according to the methodology described by Neumann et al. (2007), which considers the difference in nutrients found in dry matter lost, i.e. what was lost in emptying the silo get the percentage points that were in $\mathrm{CP}, \mathrm{NDF}$ and ADF.

Data were subjected to analysis of variance, and when there was no significant effect for the factors assessed, as an average comparison test we used the Tukey Test, 5\% level of significance, using the statistical package SISVAR (FERREIRA, 2000).

\section{Results and Discussion}

The chemical composition and $\mathrm{pH}$ of silage are shown in Table 2, and according to the data presented, no significant effects were verified $(\mathrm{P}>0.05)$ for additives for NDF and TDN. However, significant effects $(\mathrm{P}<0.05)$ were observed for $\mathrm{DM}$, $\mathrm{CP}, \mathrm{ASH}$ and $\mathrm{pH}$. The sugar cane used for silage showed average levels of DM (30.72), CP (1.49) and NDF (46.12). Significant differences were observed in DM content between treatments, and the highest were obtained in silages with urea and cornmeal. Treatment with molasses was no effect, but relatively low compared to other silages. The greatest losses occurred in fermentative DM silage, inoculant added. Some factors may interfere with greater or lesser fermentative loss, among them, the mincing of the material to be silage, since particles that are too small can cause increased production of wastewater (RIBEIRO et al., 2010). 
Table 2. Chemical composition, dry matter (DM), crude protein (CP), neutral detergent fiber (NDF), ether extract (EE), ash (ASH), total digestible nutrients (TDN) and $\mathrm{pH}$ of sugar cane silage with different additives.

\begin{tabular}{lcccccc}
\hline \multicolumn{1}{c}{ Treatments } & DM\% & CP\% & NDF\% & ASH\% & TDN\% & pH \\
\hline Control & $22,35 \mathrm{AB}$ & $1,94 \mathrm{~B}$ & $65,17 \mathrm{~A}$ & $3,50 \mathrm{~B}$ & $56,61 \mathrm{~A}$ & $3,40 \mathrm{C}$ \\
Corn meal & $28,68 \mathrm{~A}$ & $2,05 \mathrm{~B}$ & $60,44 \mathrm{~A}$ & $6,69 \mathrm{~A}$ & $58,58 \mathrm{~A}$ & $3,93 \mathrm{~A}$ \\
Molasses & $24,47 \mathrm{~B}$ & $1,58 \mathrm{~B}$ & $61,81 \mathrm{~A}$ & $2,99 \mathrm{C}$ & $58,01 \mathrm{~A}$ & $3,66 \mathrm{~B}$ \\
Urea & $28,05 \mathrm{~A}$ & $21,56 \mathrm{~A}$ & $56,28 \mathrm{~A}$ & $2,66 \mathrm{C}$ & $60,32 \mathrm{~A}$ & $3,50 \mathrm{C}$ \\
Inoculant & $20,59 \mathrm{C}$ & $1,74 \mathrm{~B}$ & $66,23 \mathrm{~A}$ & $2,98 \mathrm{C}$ & $56,16 \mathrm{~A}$ & $3,41 \mathrm{C}$ \\
\hline$* * \mathrm{CV} \%$ & 7,26 & 19,40 & 11,69 & 10,10 & 5,05 & 6,96 \\
\hline
\end{tabular}

* Means followed by the same capital letter in the same column do not differ by Tukey test $(\mathrm{P}>0.05)$

** Coefficient of variation.

The largest concentrations of $\mathrm{CP}$ were obtained with the addition of $2 \%$ of urea $(21.56 \% \mathrm{CP})$, which differed from the CP $1.74 \%$ in DM of the silages with the addition of inoculants or $2.05 \% \mathrm{CP}$ in DM of the silage added $10 \%$ of cornmeal. In turn, silages with the addition of $10 \%$ of molasses, showed the lowest levels of CP (1.58\%), when compared to other silages produced with the addition of several additives. You can justify this fact, the urea is a source of non-protein nitrogen, thereby raising crude protein food.

In a survey of sugar cane silage with different levels of babassu bran added, Rezende et al. (2011) observed that the silage with a greater concentration of bran presented the highest content of CP (8.9\%), and in lower concentrations, protein levels reached 7\% CP. According to Silva and Leão (1979), this would be the minimum needed to keep the rumen properly functioning, due to the intake of protein for microorganisms.

Despite the treatments that do not present a significant difference, there was decrease in NDF content using urea as an additive; this is due to the fact that the use of this in treatment bulky promotes changes in the fibrous fraction (SULIVAM, 1966) with partial solubilization of hemicellulose, resulting in a decrease in NDF content.

The average content of ash of silages containing added molasses, urea and inoculant showed a reduction in mineral fraction compared to the control, corroborating with a study conducted by Schmidt et al. (2007). This has possibly elapsed from effluent production and leaching, which, however, have not been quantified in this study. According to Valeriano et al. (2009), the levels of ash in sugar cane are usually low, and the oscillations in gray levels can be used to estimate values of DM loss during fermentation.

Teixeira et al. (2008) found $\mathrm{pH}$ variation of 3.7 to 4.1 for elephant grass silage; and as observed in this study, where the $\mathrm{pH}$ was 3.4 to 4.0 , the variation and the silage additive with cornmeal presented the best $\mathrm{pH}, 3.93$, when compared to other additives. These data corroborate with what was recommended by McDonald (1981), who states that the $\mathrm{pH}$ range great for adequate fermentation lies between 3.6 and 4.2.

No significant effects were verified $(\mathrm{P}>0.05)$ for additives for values of NDF and HEM. However, significant effects were verified $(\mathrm{P}<0.05)$ for $\mathrm{DM}$, LIG, CEL, CNF and CHOT (Table 3). 
Table 3. Average percentage of dry matter content (DM), neutral detergent fiber (NDF), hemicellulose (HEM), lignin (LIG), cellulose (CEL), non-fiber carbohydrates (NFC) and total carbohydrates (CHOT) in sugar cane silages with different additives.

\begin{tabular}{lccccccc}
\hline \multicolumn{1}{c}{ Treatments } & DM\% & NDF\% & HEM & LIG & CEL & NFC & CHOT \\
\hline Control & $22,35 \mathrm{AB}$ & $65,17 \mathrm{~A}$ & $14,88 \mathrm{~A}$ & $6,08 \mathrm{AB}$ & $44,21 \mathrm{~A}$ & $28,39 \mathrm{~A}$ & $93,57 \mathrm{~A}$ \\
Corn meal & $28,68 \mathrm{~A}$ & $60,44 \mathrm{~A}$ & $20,58 \mathrm{~A}$ & $6,59 \mathrm{~A}$ & $29,96 \mathrm{BC}$ & $32,72 \mathrm{~A}$ & $89,85 \mathrm{~A}$ \\
Molasses & $24,47 \mathrm{~B}$ & $61,81 \mathrm{~A}$ & $21,23 \mathrm{~A}$ & $2,64 \mathrm{C}$ & $37,94 \mathrm{ABC}$ & $32,91 \mathrm{~A}$ & $94,73 \mathrm{~A}$ \\
Urea & $28,05 \mathrm{~A}$ & $56,28 \mathrm{~A}$ & $24,08 \mathrm{~A}$ & $4,26 \mathrm{ABC}$ & $27,94 \mathrm{C}$ & $17,82 \mathrm{~B}$ & $74,09 \mathrm{C}$ \\
Inoculant & $20,59 \mathrm{C}$ & $66,23 \mathrm{~A}$ & $23,61 \mathrm{~A}$ & $3,21 \mathrm{BC}$ & $39,41 \mathrm{AB}$ & $27,93 \mathrm{~A}$ & $94,16 \mathrm{~A}$ \\
\hline$* * \mathrm{CV} \%$ & 7,26 & 11,69 & 20,91 & 54,44 & 7,9 & 27,99 & 1,35 \\
\hline
\end{tabular}

* Means followed by the same capital letter in the same column do not differ by Tukey test $(\mathrm{P}>0.05)$.

$* *$ Coefficient of variation.

In relation to levels of NDF, a small decrease was observed when urea was used as silage additive, although a significant effect was not verified. This fact can probably be explained by the action of ammonia to solubilize cell wall components. Results similar to those of NDF were found by Zanine et al. (2007); they obtained values of NDF equal to $62.37 \%$ after addition of urea, showing a reduction when the initial value NDF was $67.4 \%$.

An increase in levels of NDF was verified, as well as a reduction of the levels of CNF during anaerobic and aerobic phases. The CNF concentration was greater in silage with molasses than silage without additive. Balieiro Neto et al. (2009) found that concentrations of CNF silage inoculant were larger when compared to silage without additives. Schmidt et al. (2007) observed elevation in the levels of NDF in silage plus urea and a reduced content of soluble carbohydrates after the silage in relation to sugar cane in natura.

Before the silage, the value of NDF medium in all treatments was $46.12 \%$, after silage this value went up to $62.77 \%$. This increase in the levels of NDF after silage corroborates with the results obtained by Santos et al. (2006), who evaluated the chemical composition of sugar cane, and verified the content of NDF of 56.88 to $70.36 \%$. The increase in the levels of NDF is justified by the decrease in levels of soluble carbohydrates during the process of alcoholic fermentation, proportionally increasing the levels of cell wall constituents (BERNARDES et al., 2007).

According to Pedroso et al. (2007), the levels of NDF of silage treated with urea at 1 and 1.5 suffered small additions during the conservation of silage and approximately 10 were lower than those of control silage. In the literature, studies are found (BALIEIRO NETO et al., 2007; SIQUEIRA et al., 2007) that show the efficiency of the use of chemical additives to reduce the concentrations of lignin, since these are phenolic compounds and act as the main limiting factor of the degradation of fibrous fraction of fodder plants.

According to the results presented in Table 4, no significant effects were verified $(\mathrm{P}>0.05)$ of additives on losses of DM, NDF and TDN. However, significant effects were observed for CP loss and ASH.

Clamped sugar cane presented a loss of $5.86 \%$ average dry matter, independent of the use of additives. The CP content differed only when additive with urea the $2 \%$ natural matter, where there has been an increase of $19.78 \%$ of CP in DM, corroborating with results found by Pedroso et al. (2007) who found that DM loss of $6.56 \%$ and additions of $19.5 \%$ to $\mathrm{CP}$ when they made the use of urea $(1.5 \%$ in DM) as a feed additive for sugar cane silage. 
Table 4. Dry matter losses (DML\%), crude protein losses (CPL\%), neutral detergent fiber losses (NDFL\%), ash losses $(\mathrm{AL} \%)$, total digestible nutrients losses (TDNL\%) in sugar cane silage with different additives.

\begin{tabular}{lccccc}
\hline \multicolumn{1}{c}{ Treatments } & DML\% & CPL\% & NDFL\% & AL\% & TDNL\% \\
\hline Control & $6,078 \mathrm{~A}$ & $0,53 \mathrm{~B}$ & $16,17 \mathrm{~A}$ & $-0,06 \mathrm{C}$ & $6,74 \mathrm{~A}$ \\
Corn meal & $5,32 \mathrm{~A}$ & $0,74 \mathrm{~B}$ & $19,37 \mathrm{~A}$ & $-1,58 \mathrm{~A}$ & $8,08 \mathrm{~A}$ \\
Molasses & $4,63 \mathrm{~A}$ & $0,50 \mathrm{~B}$ & $14,98 \mathrm{~A}$ & $-0,70 \mathrm{BC}$ & $6,25 \mathrm{~A}$ \\
Urea & $5,63 \mathrm{~A}$ & $-19,78 \mathrm{~A}$ & $7,16 \mathrm{~A}$ & $-0,57 \mathrm{BC}$ & $2,99 \mathrm{~A}$ \\
Inoculant & $7,69 \mathrm{~A}$ & $0,11 \mathrm{~B}$ & $18,30 \mathrm{~A}$ & $-0,96 \mathrm{AB}$ & $7,63 \mathrm{~A}$ \\
\hline$* * * \mathrm{CV} \%$ & 35,66 & 26,53 & 46,60 & 44,62 & 46,60 \\
\hline
\end{tabular}

* Means followed by the same capital letter in the same column do not differ by Tukey test $(\mathrm{P}>0.05)$

** Medium preceded by a negative sign indicates increase in the percentage.

*** Coefficient of variation.

The increase in $\mathrm{CP}$ of dough before being compared to clamped silage material, is probably related to the use of soluble carbohydrates, causing a percentage increase in levels of CP (VALERIANO et al., 2009). The losses of NDF, TDN and ASH showed no statistical differences among treatments.

Losses of dry matter silage in our study did not differ among treatments, unlike the result found by Pedroso et al. (2007) who observed losses of DM $18.3 \%$, and Freitas et al. (2006b) who found even greater value (31\%) for losses of DM.

Balieiro Neto et al. (2009) studied fermentative losses in silage with added lime, concluded that the additive did not reduce dry matter losses during sugar cane silage; however, Freitas et al. (2006b) proved that the inclusion of soybean residue (additive) in sugar cane silage, smaller losses of DM when compared to the control and treatment with microbial additives, and compared to results verified by Kung Junior and Stanley (1982) and DM losses equivalent to $29 \%$ for rod clamped.

When evaluating characteristics of fermentation of sugar cane silage treated with urea, Freitas et al. (2006b) concluded that the sugar cane silage was characterized by loss of dry matter and soluble carbohydrates, and additives evaluated were not efficient in preventing the losses during fermentation. Siqueira et al. (2007) concluded that the treatment of sugar cane with Lactobacillus buchneri and $\mathrm{NaOH}$ minimizes quantitative losses during fermentation.

There was a difference for contents of volatile fatty acids in silage (Table 5), where the average value for lactic acid was $0.33 \% \mathrm{DM}$ acetic acid and $0.36 \%$ DM representing the relationship: lactic : acetic $0.91: 1$. The lactic relationship: acetic verified in a study conducted by Schmidt et al. (2007) was $0.43: 1$, and according to the author, these values are considered abnormal for silage sugar cane. The values found in this study were lower than those reported by Kung Junior and Stanley (1982), who found that levels of 5.6 and $1.9 \% \mathrm{DM}$ to lactic and acetic acids, which represent a relationship of lactic: acetic 2.95:1:0 cane silage. This can be justified by the low production of lactic acid, due to the smaller population and/or lactic acid bacteria activity in silages. 
Table 5. Levels of volatile fatty acids and the production of ethanol from sugar cane silage with different additives.

\begin{tabular}{lccccc}
\hline \multirow{2}{*}{ Treatments } & \multicolumn{5}{c}{ DM\% } \\
\cline { 2 - 6 } & Butyric acid & Acetic acid & Propionic acid & Lactic acid & Ethanol \\
\hline Control & $0,0045 \mathrm{~A}$ & $0,31 \mathrm{~A}$ & $0,02 \mathrm{~A}$ & $0,29 \mathrm{~A}$ & $1,91 \mathrm{~B}$ \\
Corn meal & $0,01 \mathrm{~B}$ & $0,63 \mathrm{~B}$ & $0,063 \mathrm{~B}$ & $0,35 \mathrm{AB}$ & $1,50 \mathrm{~B}$ \\
Molasses & $0,0035 \mathrm{~A}$ & $0,29 \mathrm{~A}$ & $0,018 \mathrm{~A}$ & $0,37 \mathrm{~B}$ & $1,50 \mathrm{~B}$ \\
Urea & $0,0035 \mathrm{~A}$ & $0,34 \mathrm{~A}$ & $0,02 \mathrm{~A}$ & $0,30 \mathrm{AB}$ & $1,53 \mathrm{~B}$ \\
Inoculant & $0,0044 \mathrm{~A}$ & $0,27 \mathrm{~A}$ & $0,019 \mathrm{~A}$ & $0,34 \mathrm{AB}$ & $0,86 \mathrm{~A}$ \\
\hline$* * * \mathrm{CV} \%$ & 2,25 & 17,13 & 24,43 & 10,65 & 22,69 \\
\hline
\end{tabular}

* Means followed by the same capital letter in the same column do not differ by Tukey test $(\mathrm{P}>0.05)$

** Medium preceded by a negative sign indicates increase in the percentage

$* * *$ Coefficient of variation.

The levels of butyric acid found can be considered negligible within all treatments, and this corroborates with de Andrade et al. (2000) who researched cane silages subjected to different treatments. This correlation of results between the different experiments can probably be explained by the rapid drop in $\mathrm{pH}$ in silage materials. This fact would cause inhibition of the development of clostridium in silages, thus limiting the production of butyric acid (MUCK, 1993; VAN SOEST, 1994). A low production of butyric acid was observed in this study. According to Schmidt et al. (2007) this indicates that undesirable changes did not occur inside the clamped batter, except for high ethanol production.

For propionic acid (Table 5), the levels are considered low, with an average of $0.028 \%$ DM. Schmidt et al. (2007) pointed out that there are few studies reporting on the VFA composition in sugar cane silage.

The lowest concentrations of lactic acid observed in sugar cane silage may be related to the ability of yeasts to use this acid as an energy source. The present work verified the highest content of lactic acid in silage added molasses $10 \%$. Freitas et al. (2006a) when using L. plantarum; L. buchneri; L. plantarum + residue; L. buchneri + residue, and soy residue, concluded that the highest concentrations of lactic acid were found in silage added with
Lactobacillus plantarum and Lactobacillus buchneri, i.e. microbial inoculants, discarding the hypothesis that waste is responsible for the increase of lactic acid content.

According to Alli et al. (1983), high ethanol production means that there has been significant development of yeasts, which in addition to increasing the loss of DM and ADF levels, contributes to the low production of lactic acid.

Preston et al. (1976) and Kung Junior and Stanley (1982) suggested values for ethanol sugar cane clamped without the use of additives, as between 5.5 and $15.5 \%$; the data found in this work can be considered very low, since the value found for silage was $1.91 \%$ control, which is interesting, because it implies a lower presence of yeasts in silage material.

In studies on the effects of aeration on the characteristics of sugar cane silage, Silva et al. (2009) observed the occurrence of high ethanol production, independent of the time of airing, and concluded that the difference in handling (aeration) silage did not alter the development of yeasts, and managed to produce high amounts of ethanol, having an average of $22.20 \%$. Andrade et al. (2001) observed levels of ethanol from 7.8 to $17.5 \% \mathrm{DM}$ in sugar cane silage with no additives, which resulted in losses of up to $29 \%$ of the DM of silage, while Castrillón et al. (1978) observed concentrations 
of ethanol from $5.1 \%$ in sugar cane silage without using additives.

\section{Conclusions}

The use of additives does not promote the reduction of losses of DM, NDF, TDN, but promotes improvements in fermentation of carbohydrates and fibrous fraction of sugar cane silage. Urea proved to be an interesting alternative to increase the nutritional value of sugar cane silage.

\section{References}

ALLI, I.; FAIRBAIRN, R.; BAKER, B. E. The effects of ammonia on the fermentation of chopped sugar cane. Animal Feed Science and Technology, Netherland, v. 9, n. 4, p. 291-299, 1983.

ANDRADE, J. B.; FERRARI JUNIOR, E.; BRAUN, G. Valor nutritivo da silagem de cana de açúcar tratada com ureia e acrescida de rolão-de-milho. Pesquisa Agropecuária Brasileira, Brasília, v. 36, n. 9, p. 11691174, 2001.

ANDRADE, J. B.; FERRARI JÚNIOR, E.; POSSENTI, R. A.; LEINZ, F. F.; BIANCHINI, D.; RODRIGUES, C. F. C. R. Aditivo biológico na ensilagem de cana de açúcar tratada com ureia. Boletim de Indústria Animal, Nova Odessa, v. 57, n. 2, p. 139-149, 2000.

BALIEIRO NETO, G.; FERRARI, E. J.; NOGUEIRA, J. R.; POSSENTI, R.; PAULINO, V. T.; BUENO, M. S. Perdas fermentativas, composição química, estabilidade aeróbia e digestibilidade aparente de silagem de cana de açúcar com aditivos químico e microbiano. Pesquisa Agropecuária Brasileira, Brasília, v. 44, n. 6, p. 621-630, 2009.

BALIEIRO NETO, G.; SIQUEIRA, G. R.; REIS, R. A.; NOGUEIRA, J. R.; ROTH, M. T. P.; ROTH, A. P. T. P. Óxido de cálcio como aditivo na ensilagem de cana de açúcar. Revista Brasileira de Zootecnia, Viçosa, v. 36, n. 5, p. 1231-1239, 2007.

BERNARDES, T. F.; REIS, R. A.; SIQUEIRA, G. R.; BERCHIELLI, T. T.; COAN, R. M. Avaliação da queima e da adição de milho desintegrado com palha e sabugo na ensilagem de cana-de-açúcar. Revista Brasileira de Zootecnia, Viçosa, v. 36, n. 2, p. 269-275, 2007.

CAPPELLE, E. R.; FILHO, S. C. V.; SILVA, J. F. C.; CECON, P. R. Estimativas do valor energético a partir de características químicas e bromatológicas dos alimentos.
Revista Brasileira de Zootecnia, Viçosa, MG, v. 30, n. 6, p. 1837-1856, 2001.

CASTRILLÓN, M. V.; SHIMADA, A. S.; CALDERÓN, F. M. Manipulación de la fermentación en ensilajes de cana de azúcar y su valor alimenticio para borregos. Técnica Pecuaria en México, v. 35, n. 1, p. 48-55, 1978.

DELGADO, A. A. Tecnologia do açúcar e das fermentações industriais. In: . Tecnologia dos produtos agropecuários. Piracicaba: ESALQ, 1975. v. 1, p. 91.

FERREIRA, D. F. Sistema de análises de variância para dados balanceados. Lavras: UFLA, 2000. (SISVAR 4. 1. pacote computacional).

FREITAS, A. W. P.; PEREIRA, J. C.; ROCHA, F. C.; COSTA, M. G.; LEONEL, F. P.; RIBEIRO, M. D. Avaliação da qualidade nutricional da silagem de cana de açúcar com aditivos microbianos e enriquecida com resíduo da colheita de soja. Revista Brasileira de Zootecnia, Viçosa, MG, v. 35, n. 1, p. 38-47, 2006a.

FREITAS, A. W. P.; PEREIRA, J. C.; ROCHA, F. C.; DETMANN, E.; RIBEIRO, M. D.; COSTA, M. G.; LEONEL, F. P. Características da silagem de cana de açúcar tratada com inoculante bacteriano e hidróxido de sódio e acrescida de resíduo da colheita de soja. Revista Brasileira de Zootecnia, Viçosa, MG, v. 35, n. 1, p. 4859, 2006b.

KUNG JUNIOR, L.; STANLEY, R. W. Effect of stage of maturity on the nutritive value of whole-plant sugar cane preserved as silage. Journal of Animal Science, Champaign, v. 54, n. 4, p. 689-696, 1982.

McDONALD, P. The biochemistry of silage. New York: John Wiley \& Sons, 1981. 207 p.

MUCK, R. E. The role of silage additives in making high quality silage. In: . Silage production from seed to animal. Ithaca: Northeast Regional Agricultural Engineering Service, Cooperative Extension, 1993. p. 106-116.

NEUMANN, M.; MUHLBACH, P. R. F.; NORNBERG, J. L.; RESTLE, J.; OST, P. R. Efeito do tamanho de partícula e da altura de colheita das plantas de milho (Zea mays L.) sobre perdas durante o processo fermentativo e período de utilização das silagens. Revista Brasileira de Zootecnia, Viçosa, MG, v. 36, n. 5, p. 1395-1405, 2007.

PÁDUA, F. T.; FONTES, C. A. A.; ALMEIDA, J. C. C.; DEMINICIS, B. B.; ALMEIDA, C. L.; CABRAL NETO, O.; OLIVEIRA, V. C. Fermentation characteristics of silage of sugar cane treated with calcium oxide, Lactobacillus buchneri and their associations. American Journal of Plant Sciences, Coulterville, v. 5, n. 5, p. 636646, 2014. 
PALMQUIST, D.; CONRAD, H. Origin of plasma fatty acids in lactating cows fed high fat diets. Journal of Dairy Science, Madison, v. 54, n. 7, p. 1025-1033, 1971.

PEDROSO, A. F.; NUSSIO, L. G.; LOURES, D. R. S.; PAZIANI, S. F.; IGARASI, M. S.; COELHO, R. M.; HORII, J.; RODRIGUES, A. A. Efeito do tratamento com aditivos químicos e inoculantes bacterianos nas perdas e na qualidade de silagens de cana de açúcar. Revista Brasileira de Zootecnia, Viçosa, MG, v. 36, n. 3, p. 558-564, 2007.

PIRES, A. V.; SUSIN, I.; SIMAS, J. M. C.; OLIVEIRA JÚNIOR, R. C.; FERNANDES, J. J. R.; ARAUJO, R. C.; MENDES, C. Q. Substituição de silagem de milho por cana de açúcar e caroço de algodão sobre o desempenho de vacas holandesas em lactação. Ciência Animal Brasileira, Goiânia, v. 11, n. 2, p. 251-257, 2010.

PRESTON, T. R.; HINOJOSA, C.; MARTINEZ, L. Ensiling of sugar cane with ammonia molasses and mineral acids. Tropical Animal Health and Production, v. 1, p. 120-126, 1976.

REZENDE, A. A. S.; PASCOAL, L. A. F.; VAN CLEEF, E. H. C. B.; GONÇALVES, J. S.; OLSZEVSKI, N.; BEZERRA, A. P. A. Composição química e características fermentativas de silagens de cana de açúcar contendo farelo de babaçu. Archivos de Zootecnia, Córdoba, v. 60, n. 232, p. 1031-1039, dez. 2011.

RIBEIRO, L. S. O.; PIRES, A. J. V.; CARVALHO, G. G. P.; SANTOS, A. B.; FERREIRA. A. R.; BONOMO, P.; SILVA, F. F. Composição química e perdas fermentativas de silagem de cana de açúcar tratada com ureia ou hidróxido de sódio. Revista Brasileira de Zootecnia, Viçosa, MG, v. 39, n. 9, p. 1911-1918, 2010.

SANTOS, R. V.; EVANGELISTA, A. R.; PINTO, J. C.; COUTO FILHO, C. C. C.; SOUZA, R. M. Composição química da cana-de-açucar (Saccharum, spp.) e das silagens com diferentes aditivos em duas idades de corte. Ciência e Agrotecnologia, Lavras, v. 30, n. 6, p. 11841189, 2006.

SCHMIDT, P.; MARI, L. J.; NUSSIO, L. G.; PEDROSO, A. F.; PAZIANI, S. F.; WECHSLER, F. S. Aditivos químicos e biológicos na ensilagem de cana de açúcar. 1. Composição química das silagens, ingestão, digestibilidade e comportamento ingestivo. Revista Brasileira de Zootecnia, Viçosa, MG, v. 36, n. 5, p. 16661684, 2007. Suplemento 2.
SILVA, D. J.; QUEIROZ, A. C. Análise de alimentos: métodos químicos e biológicos. 3. ed. Viçosa, MG: Editora UFV, 2009. 235 p.

SILVA, E. J. A.; BORGATTI, L. M. O.; MEYER, P. M.; RODRIGUES, P. H. M. Efeitos da aeração sobre as características da silagem de cana de açúcar. Acta Scientiarum Agronomy, Maringá, v. 31, n. 2, p. 247-253, 2009.

SILVA, J. F. C.; LEÃO, M. I. Fundamentos de nutrição de ruminantes. Piracicaba: Ed. Livroceres, 1979. 384 p.

SIQUEIRA G. R.; REIS, R. A.; SCHOKEN-ITURRINO, R. P.; BERNARDES, T. F.; PIRES, A. J. V.; ROTH, M. T. P.; ROTH, A. P. T. P. Associação entre aditivos químicos e bacterianos na ensilagem de cana de açúcar. Revista Brasileira de Zootecnia, Viçosa, MG, v. 36, n. 4, p. 789798, 2007.

SULLIVAN, J. T. Studies of the hemicelluloses of forage plants. Journal of Animal Science, Champaign, v. 25, n. 1, p. 83-86, 1966.

TEIXEIRA, F. A.; VELOSO, C. M.; PIRES, A. V.; SILVA, F. F.; NASCIMENTO, P. V. N. Perdas na ensilagem de capim-elefante aditivado com farelo de cacau e cana de açúcar. Arquivo Brasileiro de Medicina Veterinária e Zootecnia, Belo Horizonte, v. 60, n. 1, p. 227-233, 2008.

VALERIANO, A. R.; PINTO, J. C.; AVILA, C. L. S.; EVANGELISTA, A. R.; TAVARES, V. B.; SCHWAN, R. F. Efeito da adição de Lactobacillus sp. na ensilagem de cana-de-açucar. Revista Brasileira de Zootecnia, Viçosa, MG, v. 38, n. 6, p. 1009-1017, 2009.

VAN SOEST, P. J. Nutritional ecology of the ruminant. $2^{\text {th }}$ ed. Ithaca: Cornell University, 1994. 476 p.

ZANINE, A. M.; SANTOS, E. M.; FERREIRA, D. J.; PEREIRA, O. G. Efeito de níveis de ureia sobre o valor nutricional do feno de capim-tanzânia. Semina: Ciências Agrárias, Londrina, v. 28, n. 2, p. 333-340, 2007. 